\title{
嗅神経芽細胞腫に対する内視鏡下経鼻手術一その術式の検討
}

\author{
中川隆之 ${ }^{1)}$, 児玉 悟2), 小林 正 佳 ${ }^{3)}$, \\ 荻 野 枝里子 ${ }^{1)}$, 坂 本 達 則 $^{1)}$, 伊 藤 壽 -1) \\ ${ }^{1)}$ 京都大学大学院医学研究科耳鼻咽诶科・頭頸部外科 \\ ${ }^{2}$ 大分大学医学部耳鼻咽喉科 \\ ${ }^{3)}$ 三重大学大学院医学研究科耳鼻咽峽科・頭頸部外科
}

近年, 嗅神経芽細胞腫に対する内視鏡下経鼻手術の有効性が数多く報告されているが, 有効性検証を目的と した前向き臨床試験の報告はない。本研究では, 将来的な前向き臨床試験の基準とする術式確立を目的として, 内視鏡下経鼻手術を行った嗅神経芽細胞腫 5 例を対象とした後ろ向き研究を行った。対象は女性 1 例, 男性 4 例であり，臨床病期はDulguerovの病期分類でT1，2例（Kadish A，1例， B， 1 例)，T2，3 例（Kadish C, 3例）であった。内視鏡下経鼻手術では, 穊骨洞天蓋, 上, 中鼻甲介, 篩板, 嗅系の切除を原則とし, 詳細な 切除範囲は術中病理検査にて決定し, 全例術後放射線治療を行った。病理組織学的な断端における腫瘍浸潤の 有無, 再発の有無, 嗅覚温存, 合併症について解析した。結果, 12-51ヶ月の観察期間中再発は認められず, 3 例で嗅覚が温存され, 術後合併症は認めなかった。病理組織学的には, 篩板浸潤が疑われるT2, 1 例で嗅 糸周辺硬膜にて腫瘍細胞が認められた。以上の結果から, 篩板浸潤が疑われるT2症例では, より厳密な嗅系 を含めた硬膜の術中病理診断を行い，切除範囲を決定すべき事が示唆された。

キーワード : 前頭蓋底, 嗅神経芽細胞腫, 内視鏡, 拡大経鼻アプローチ

\section{Endoscopic Endonasal Resection of Olfactory Neuroblastomas: Our Experience}

\author{
Takayuki Nakagawa ${ }^{1)}$, Satoru Kodama ${ }^{2)}$, Masayoshi Kobayashi ${ }^{3)}$, \\ Tatsunori Sakamoto $^{1)}$, Eriko Ogino-Nishimura ${ }^{1)}$, Juichi Ito ${ }^{1)}$
}

\footnotetext{
${ }^{1)}$ Department of Otolaryngology, Head and Neck Surgery, Graduate School of Medicine, Kyoto University ${ }^{2)}$ Department of Otorhinolaryngology and Head \& Neck Surgery, Faculty of Medicine, Oita University ${ }^{3)}$ Department of Otorhinolaryngology, Head and Neck Surgery, Graduate School of Medicine, Mie University
}

The objective of this study was to establish a standard surgical procedure for endoscopic endonasal resection of olfactory neuroblastomas for future prospective clinical studies. We retrospectively reviewed 5 patients (4 males, 1 female) who underwent primary endoscopic endonasal resection of olfactory neuroblastomas. Of these, the Dulguerov stage at presentation was T1 in 2 patients (Kadish A and B in 1 each) and T2 (Kadish C) in 3 patients. The endoscopic endonasal surgery involved the resection of the middle and superior turbinates, cribrioform plate, ethmoidal fovea and olfactory fila with the intraoperative histological analyses of the margins. The main parameters compared were margin assessment, prognosis, preservation of olfaction, and complications. In one T2 case, tumor cells were identified in the margins of the olfactory fila, while resection with negative margins was achieved in the other 4 cases. No recurrence was found during observation periods ranging from 12 to 51 months (median: 25 months). Olfaction was maintained in 3 patients. 
No postoperative complications were identified. These findings indicated that more precise studies of intraoperative margin in the olfactory fila and dura matter are required for T2 patients.

Key words : anterior skull base, esthesioneuroblastoma, endoscopy, expanded endonasal approach

(2012年 7 月 25 日受稿，2012年 9 月13日受理)

\section{緒言}

近年, 手術器機および手術手技の進歩に伴い, 内視鏡 下経鼻手術の適応は, 鼻副鼻腔の炎症性, 腫瘍性病変か ら頭蓋底, 眼窩, 翼口蓋窩の炎症性, 腫瘍性病変へと拡 大しつつある。頭蓋底疾患については, 良性腫瘍に加え, 一部の悪性腫瘍も内視鏡下経鼻手術が用いられている1)。 嗅裂に発生することが多い嗅神経芽細胞腫も近年内視鏡 下経鼻手術が用いられることが多い疾患であり，侵襲の 少ない内視鏡下経鼻手術を第一選択とする報告も散見さ れる2,3)。嗅神経芽細胞腫は, 鼻副鼻腔腫瘍の $0.25 \%$, 鼻 腔悪性腫瘍の $5 \%$ をしるとされており ${ }^{1)}$, 頻度の高い 疾患ではないが, ある程度の臨床経験を経れば, 経験す る疾患ともいえる。

近年, 外切開による手術と比較し, 嗅神経芽細胞腫治 療における内視鏡下経鼻手術の利点を示す報告がい くつかなされている。Devaiah et al. ${ }^{2)}$ は, 361例のmetaanalysisから, 外切開による手術を受けた症例と比較し て，内視鏡下経鼻手術による腫瘍切除を受けた症例の方 が，統計学的に有意に良好な生存率を示すと報告してい る。また, Folbe et $\mathrm{al}^{3}{ }^{3)}$ は, 23例の後ろ向き研究から, 外切開で行われた手術は, 内視鏡下経鼻手術に置き換え ることが可能であったとしている。これらの報告は, 嗅 神経芽細胞腫に対する手術アプローチとしての内視鏡下 経鼻手術の有用性を示唆している。一方, Soler and $\mathrm{Smith}^{4}$ は，5つの文献をもとに，嗅神経芽細胞腫の手 術治療として, 内視鏡下経鼻アプローチと外切開による アプローチのどちらが優れるのかを考察している。結論 として, 嗅神経芽細胞腫に対する手術療法として，2つ の手術アプローチを比較するエビデンスレベルの高い研 究はなく, どちらの手術アプローチを選択するかではな く, 切除断端院性である完全切除を実現することが重要 としている。その根拠として, ランダム化した術式の比 較試験を行うことは事実上不可能であること, 統計学的 な解析を行うに十分な症例を集めることが困難であるこ と, 予後の評価には長期の経過観察が必要なことをあげ ている。しかしながら，外切開による手術と比較して， 内視鏡下経鼻手術には, 低侵襲性という大きな利点があ り，嗅神経芽細胞腫に対する内視鏡下経鼻手術の位置づ
けを明確にする臨床研究が求められる。手術手技として の有効性を評価するという観点から, Soler and Smith の総説で結論されているように, 病理組織学的な完全切 除の正否が第一のポイントとなる。症例数が少なく, 単 一の施設での臨床試験が困難である点については, 多施 設で明確かつ詳細な評価方法を定めることにより解決可 能と考えられる。術式に関しても，単に内視鏡下経鼻手 術とせずに切除範囲とその方法についてもある程度基準 化することが望ましい。本論文では, 筆頭著者が施行し， 同様の術式を用いた 5 例での病理組織学的所見を元に, 基準とすべき術式について考察する。

\section{方法}

対象

筆頭著者が術者として，同一手術方法を用いて，内視 鏡下経鼻アプローチにより腫瘍切除を行った嗅神経芽細 胞腫 5 例を対象とした。術後放射線治療照射を諸家の報 告に従い全例ルチーンで施行した（T1，2 例では，ラ イナックにて 50 グレイ， T2， 3 例では，強度変調放射 線治療を用いて50あるいは60グレイ)。照射範囲は，左 右眼窩内側壁の間，篩骨洞および嗅裂をすべて含む範囲 とし, 鶏冠, 嗅球を含めた。

術式

対象とした 5 症例で行った術式について述べる。原則 として, 反対側鼻腔への浸潤が認められない場合は，片 側切除とし，嗅覚を温存することを企図した。切除範囲 を簡潔に述べると，頭蓋底側では，篩板，上および中鼻 甲介基部，嗅上皮を一塊で切除し，外側では，篩骨洞外 側粘膜への浸潤が疑われる場合は，眼窩内側壁骨切除を 追加し，正中側では，篩骨垂直板を原則切除し， 反対側 への浸潤が疑われる場合は，鵎冠，反対側篩板，上およ び中鼻甲介，嗅上皮を切除した（図 1 )。手術は，術中 迅速病理組織検査を含め, 段階的に行った。術式を理解 しやすくするために，以下に段階別に手術操作について 記載する。

1）腫瘍部分切除：腫瘍の基部は残し，適切な止血凝 固処置を行いながら，腫瘍の減量を行い，引き続き行う 第一段階の術中病理組織検査における組織採取のための 視野とスペースを確保した。主として, 中鼻甲介内側面, 

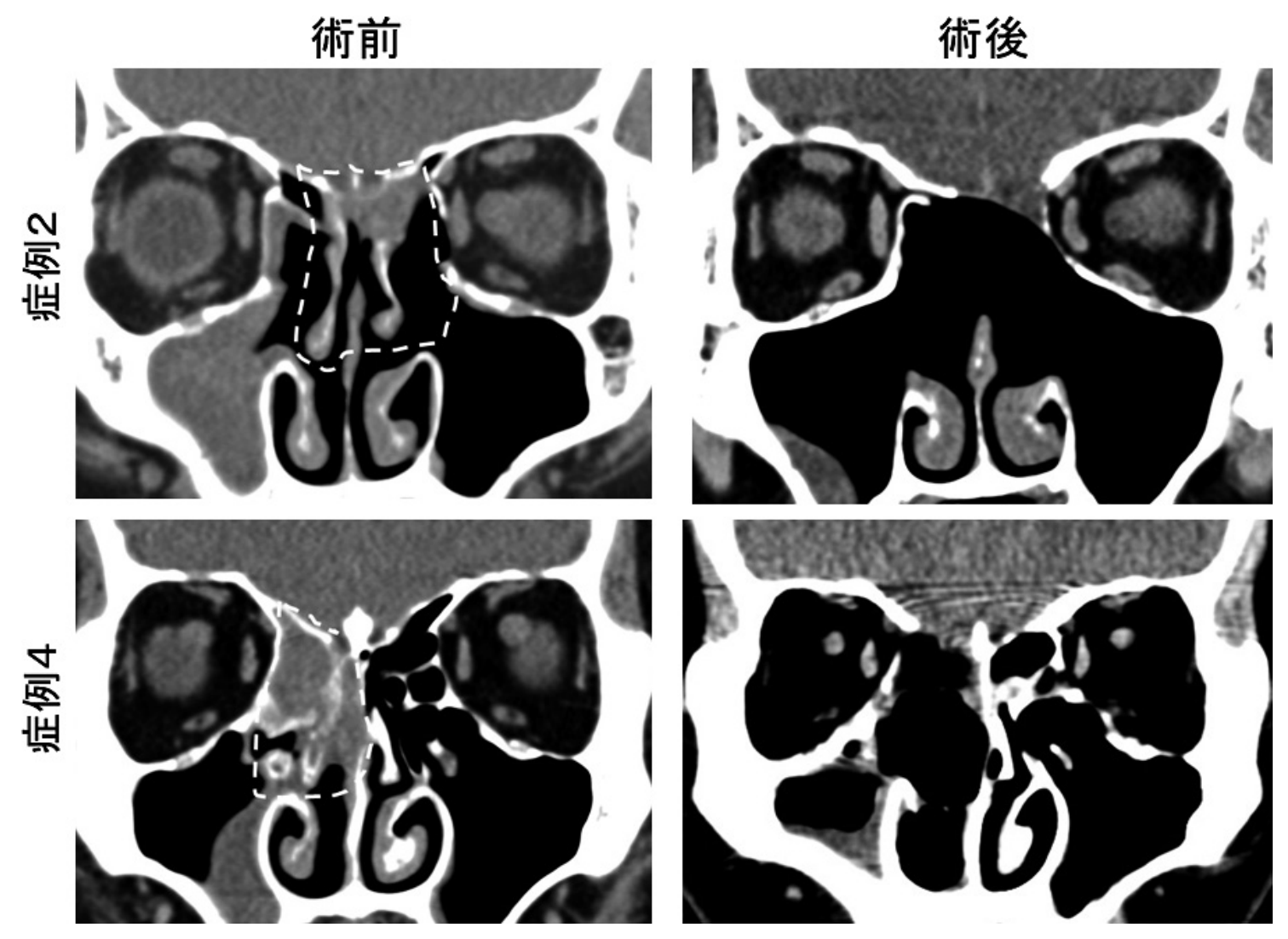

図 1 切除範囲。症例 2 では, 左側嗅裂に腫瘍が存在し, 術中病理検査にて反対側への浸潤が認められたため, 反対側笁板を含 めて切除した。症例 4 では, 右側嗅裂と篩骨洞内に腫瘍が認められ，術中病理検查にて篩骨洞粘膜に浸潤を認めたため， 眼窩内側壁も削除した。切除範囲を点線で示す。

鼻中隔，蝶篩陥凹からの組織採取に留意した腫瘍組織の 減量を施行した。腫瘍切除を行わなくても，十分な視野と スペースが得られる場合，腫瘍部分切除は行わなかった。 2) 穊骨洞蝶形骨洞手術 : 中鼻道から鈎状突起切除, 前節骨洞開放，蝶形骨洞開放を行い，眼窩内側壁がすべ て視野に入る状態とし，穊骨洞あるいは中鼻道内に腫瘍 進展が認められた場合, 上記の視野が得られるように腫 瘍部分切除を追加した。

3）鼻副鼻腔内病理組織検査: 中鼻甲介内側面, 鼻中隔, 蝶穊陥凹, 節骨洞, 蝶形骨洞, 中鼻甲介外側面, 眼窩内 側壁から組織採取し，迅速病理検查を施行した。篩骨洞 あるいは中鼻道内に腫瘍進展が認められた場合には，穊 骨洞外側（眼窩内側壁）粘膜㧍よび中鼻甲介後端部粘膜 採取を行った。初回の組織採取は, 術前画像診断に基づ き, 断端陰性となる切除範囲を想定し, 組織採取部位を 決定した。最初に想定した術中病理診断で, 断端陽性で あった場合, 追加切除を行い, 再び病理組織診断を施行 し，断端陰性となる鼻副鼻腔領域の切除を行った。

4) Draf typeIIb前頭洞手術：上記の病理組織検查結果 待ちの時間を利用して, Draf typeIIbに相当する前頭洞
底の骨削除を行い，最前方に位置する 1 本目の嗅系を露 出, 確認した（図2A）。

5 ）眼窩内側壁切除：穊骨洞粘膜への浸潤が疑われる 場合，眼窩内側壁骨とともに穊骨洞外側壁粘膜をすべて 切除した。眼窩内側壁の骨削除範囲は，前方は鈎状突起 付着部，上方は前篩骨動脈管，下方は上顎洞自然口上端 とし，いわゆる紙様板を切除し，眼窝尖では，穊骨洞ある いは蝶形骨洞粘膜剥離，切除後，骨表面の削除を行った。 6）前穊骨動脈切断：眼窩内側壁骨を一部削除し, 前 穊骨動脈を露出し，同部から正中に向かい，中鼻甲介に 至るまで前穊骨動脈を露出した。眼窩内側壁に近い部位 で凝固を行った後に, 中鼻甲介付近で凝固し，そのやや 外側で凝固切断を行った（図2B）。

7 ）篩板切除：前穊骨動脈が中鼻甲介付近で頭蓋内に 入る部分で骨削除を開始し, 硬膜を露出させ, 前頭洞後 壁に向かい, 前方へ硬膜と節板との剥離, 骨削除を進め, 前頭洞後壁に到達後，1本目の嗅糸に向かい内側に骨削 除を進めた。次に, 骨削除開始部分から, 後方に向かっ て硬膜と篩板との剥離, 骨削除を進め (図2C), 蝶形骨 前壁に達する部分で再び内側に骨削除をすすめ, 篩板を 

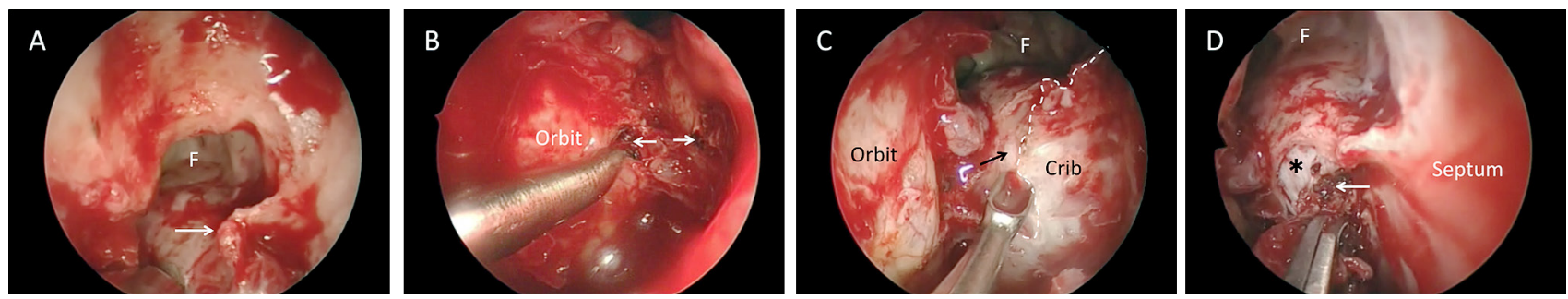

図2 内視鏡手術所見。症例 5 の内視鏡手術所見を示す。A：Draf IIbに準じて，右前頭洞（F）を開放した。矢印は最前方の嗅 糸を示す。B：一部眼窩内側壁（Orbit）削除後, 前篩骨動脈（矢印で断端を示す）を凝固切断した。C：篩板（Crib）を 硬膜 (矢印) から剥離, 切除しているところ。F：前頭洞, Orbit：眼窩骨膜。D：嗅糸を前方から凝固, 切断していると ころ (矢印)。* : 硬膜, Septum : 鼻中隔, F : 前頭洞。

硬膜から分離した。

8 ）嗅糸切断：鼻中隔粘膜の術中迅速病理組織検査結果 に従い, 鼻中隔粘膜の下方の切除線を決定し, 蝶形骨洞 前壁から前方に向かい粘膜切開を加えた。前方の断端も 術中迅速病理検査所見に従って決定するが, 少なくとも 嗅糸の 1 本目よりも前方で, 中鼻甲介の前端に相当する 位置を目安とした。鼻中隔矯正術の要領で, 鼻中隔粘膜 を軟骨膜とともに挙上し, 天蓋まで剥離を進め, 嗅系を 明視下においた。嗅糸を前方から順に凝固切断し（図 2D), 腫瘍組織を上, 中鼻甲介, 篩板, 鼻中隔粘膜とと もに一塊として摘除した。

9 ）硬膜, 嗅糸病理組織検査：この段階では, 嗅糸断端 あるいはその周辺の硬膜を採取し, 術中病理検査標本と した。

10）再建：再建方法は, 頭蓋底の骨欠損部位の大きさ, 硬膜欠損部位の大きさに応じて決定した。今回手術した 5 症例では, 広範な硬膜欠損を伴った症例はなく, 手術 操作に伴う硬膜穿孔を脂肪片によるバスプラグ法で閉鎖 し，頭蓋底骨欠損部位は大腿筋膜を頭蓋底骨と硬膜との 間にサンドイッチする形で挿入しフィブリン糊で固定し た。キチンコーティングガーゼを術後 2 日間挿入した。 評価項目

臨床的には, 年齢, 性別, Kadish ${ }^{5}$ およびDulguerov and Calcaterraの病期分類 ${ }^{6)}$, 組織学的なHymas grade ${ }^{7)}$, 切除範囲 (反対側および眼窩内側壁切除の有無), 術後 合併症の有無, 観察期間中の再発の有無, 嗅覚温存につ いて調べた。病理組織学的検査所見としては, 摘出標本 の永久病理検査にて断端陽性と診断された症例数とその 部位について調べた。

\section{結 果}

対象とした症例の年齢, 性別, 臨床的病期分類として KadishおよびDulguerov and CalcaterraのTNM病期分
類, 組織学的なHymas gradeを表 1 に示す。年齢は, 35-53（中央值47）歳, 男性 4 例, 女性 1 例であった。 術前画像診断に基づく臨床的病期分類（図 3 ）では, Kadish病期分類にてステージA 1 例, B 1 例, C 3 例, Dulguerov and CalcaterraのTNM分類では, T1N0M0： 2 例, T2N0M0：3例であった。すなわち，篩板への浸 潤が疑われない症例が 2 例, 篩板への浸潤が疑われるが, 明らかな硬膜浸潤はないと考えられる症例が 3 例という 内訳となった。Hymas grade分類では, Grade I：1例, Grade II：4 例であった。また，観察期間は，12-51（中 央值25)ヶ月であった。

すべての症例で, 術中病理診断にて断端㓌性となるよ うに切除範囲を設定した。篩骨洞外側粘膜への浸潤が認 められたT2の 1 例では, 眼窩内側壁骨切除を追加し, 反対側嗅裂および中鼻甲介嗅裂側粘膜浸潤が認められた T2の 1 例では, 両側での切除を施行した。提出標本の 永久病理診断では, $\mathrm{T} 2$ の 1 例で嗅系断端に腫瘍細胞の 残存が認められたが，他の 4 症例では，すべて断端陰性 であった（表 1 ）。

嗅覚温存については, 片側切除を行った 4 例中 3 例で, 嗅覚温存が可能であった（表 1 )。手術から術後放射線 治療開始までの期間は, 全例術後 4 週目に放射線療法を 開始することができ，術後合併症は認められなかった。 術中軽度の髄液漏が全例で認められたが, 術後髄液漏の 発生は認められず, 感染症, 術後出血も認められなかっ た。観察期間が12-51ケ月と短いため, 予後について結 論づけることはできないが, 現時点では, 腫瘍再発は認 めていない。

\section{考察}

嗅神経芽細胞腫の病期分類については, 古くからの Kadish分類が広く用いられてきた ${ }^{5)}$ 。Kadish分類では, 鼻腔内に限局する $\mathrm{A}$, 副鼻腔に進展する $\mathrm{B}$, 頭蓋, 眼窩 
表 1 症例サマリー

\begin{tabular}{|c|c|c|c|c|c|c|c|c|c|c|}
\hline 症例 & 年齢 & 性別 & Kadish & Dulguerov & Hymas graede & 追加切除 & 断端病理 & 嗅覚温存 & 術後放射線治療 & 観察期間 (月) \\
\hline 1 & 35 & $\mathrm{~F}$ & $\mathrm{~B}$ & $\mathrm{~T} 1$ & 2 & - & - & + & Linac 50Gy & 51 \\
\hline 2 & 47 & M & $\mathrm{C}$ & $\mathrm{T} 2$ & 2 & 反対側 & - & - & IMRT 60Gy & 37 \\
\hline 3 & 44 & M & $\mathrm{C}$ & $\mathrm{T} 2$ & 2 & - & + & - & IMRT 50Gy & 25 \\
\hline 4 & 47 & M & $\mathrm{C}$ & $\mathrm{T} 2$ & 2 & 眼窩内側壁 & - & + & IMRT 50Gy & 15 \\
\hline 5 & 53 & M & A & $\mathrm{T} 1$ & 1 & - & - & + & Linac 50Gy & 12 \\
\hline
\end{tabular}

\section{Dulguerov and Calcaterraの病期分類}

T1

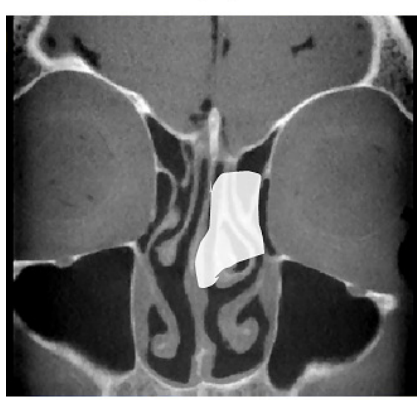

鼻腔

副鼻腔(蝶形骨洞省く)
T2

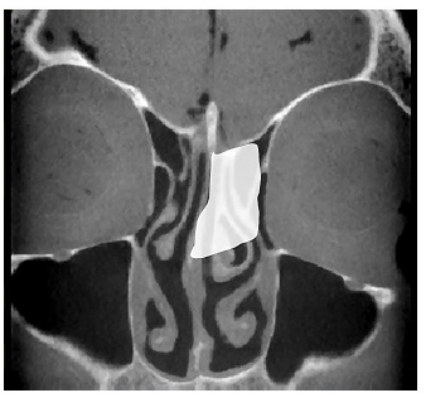

蝶形骨洞

節板への進展
T3

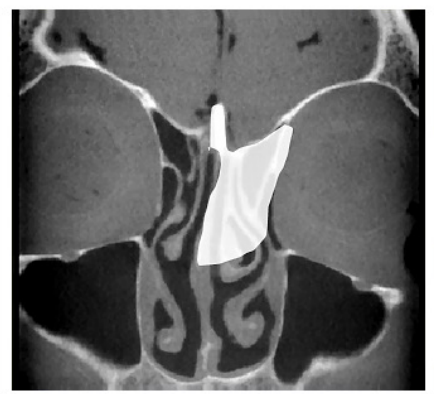

頭蓋内、眼窩進展 硬膜浸潤なし
T4

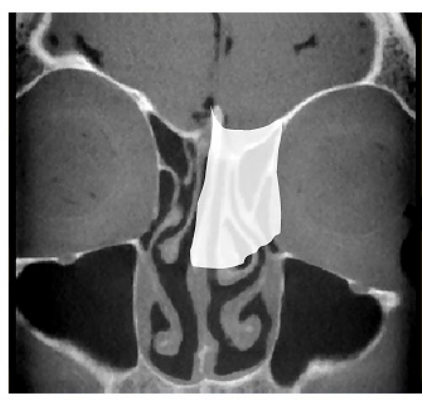

硬膜浸潤あり

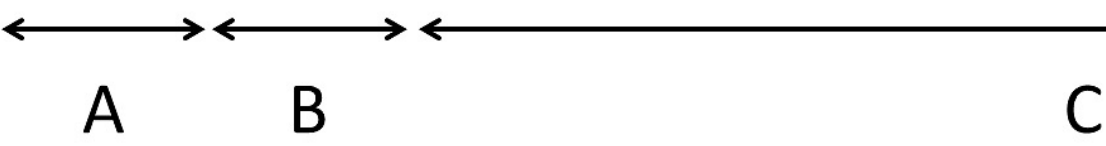

\section{Kadishの病期分類}

図3 Dulguerov and CalcaterraのT分類とKadish病期分類

内へ進展するCに分類される。より近年に発表された Dulguerov and Calcaterraの分類 ${ }^{6}$ では, KadishのA, B は, T1, KadishのCがT2からT4に分類され，篩板，硬 膜への浸潤により, 頭蓋内進展が分類されており, Computed tomography（CT）およびMagnetic resonance imaging（MR）所見に基づいた治療開始前の病期分類 として作成されている。今回用いた症例は, 術前画像診 断に基づくDulguerov and Calcaterra病期分類では, $\mathrm{T} 1 ： 2$ 例, T2：3 例, と比較的早期といえる病期に相 当するものとなる。Dulguerov et al. のmeta-analysis ${ }^{8)}$ によれば, T1の 5 年生存率は, $81 \%$, T 2 では $93 \%$ と 良好であり，T3，T4はそれぞれ $59 \% ， 48 \%$ と悪化する。 一方, Kadish分類を用いれば, A：1例, B：1例, C：
3 例となり, 早期 2 例, 進行 3 例ととらえることがで きる。Dulguerov et al.のmeta-analysisでの 5 年生存率 は，それぞれ72\%，59\%，47\%となる。Dulguerov and Calcaterra病期分類のT2は, 篩板への浸潤が認められる が，篩板を超えない，明らかな頭蓋内進展を認めない状 態であり, T3は頭蓋内進展を認めるが, 硬膜浸潤が認 められない状態とされ，T4は明らかに硬膜を含めた脳 組織への浸潤が認められる状態としている。局所制御, 手術プランニングの観点からは, Dulguerov and Calcaterra病期分類が適しているのではないかと考えら れる。また, 予後の観点からも, 篩板を超える浸潤の有 無により，5年生存率が大きく異なることから，臨床的 に有用な分類といえるが, Kadish分類も予後との相関 
性を示すとされている 類が多く用いられており，過去の文献との比較という観 点からは, Kadish分類を用い, 術式の決定には, Dulguerov and Calcaterra病期分類を用い, T1，T2症 例に対しての内視鏡下経鼻手術の有效性を検討していき たい。

今回用いた術式では，篩板を硬膜との間で剥離，切除 し, 原則篩板切除, 硬膜は可及的に温存する方針とし, 最終的な切除範囲は術中病理診断にて決定した。T2 術前診断された症例の 1 例で, 切除標本の嗅糸周辺硬膜 に腫瘍組織の残存が認められた。術中病理診断では, 最 も腫瘍に近接する嗅糸を含む硬膜をサンプルとして採取 し，陰性との診断が得られたが，他の嗅系付近の組織か ら腫瘍組織が認められた。したがって，画像診断上T2 と診断される症例でも, 顕微鏡レベルでは, 嗅糸に沿っ て頭蓋内に腫瘍が進展している可能性があり, より入念 な嗅糸および周辺硬膜の術中病理診断を行うべきである ことが示唆された。嗅糸断端で腫瘍残存が認められた症 例では，幸い術後 2 年を経て再発は認めていないが，今 後の厳重な経過観察が必要と考えている。一方, 今回用 いた術式で, 病理組織学的な断端陰性を基準とすれば, T1症例では十分な切除範囲が得られたのではないかと 考えられる。T1の 2 症例では, すべて嗅覚が温存され ており，低侵襲という内視鏡下経鼻手術の利点が活かさ れている。T1症例においては, 今回用いた術式による 片側切除を基準術式として問題ないと考えられる。

今回の結果から, Dulguerov and Calcaterraの臨床病 期分類のT2症例においては, より拡大した切除の必要 性が示唆される。患側の篩板および管骨洞天蓋に接する 部分の硬膜切除, および嗅糸の全切除を基準として行う か, 嗅系周辺の硬膜の入念な術中病理診断を施行し, 結 果に応じて拡大切除を行う，いずれかの方針が求められ る。諸家の報告を参照すると, Stammbergerのグルー プでは，基本的にわれわれが用いた術式と同様の方法を 用いている ${ }^{10)}$ 。一方, Castelnuovoのグループは, 原則 術中病理診断に従い切除範囲を決定しているが, Kadish Cであれば，基本的に硬膜，嗅球切除を行うとし ${ }^{9}$, Pittsburgh大学のグループでは, 基本的に硬膜, 嗅球切 除を両側で行う術式を用いている3)。Johns Hopkinsの グループは, 原則術中病理診断に従い切除範囲を決定し ているが，頭蓋底浸潤が疑われた場合は，硬膜，嗅神経 を腫瘍とともに切除するとしている11)。手術侵襲を考え ると, Kassamは, 内視鏡下経鼻頭蓋底手術 800 症例の解 析から, 術中, 術後合併症の有意な危険因子として, 硬 膜内操作の有無をあげている ${ }^{12)}$ 。したがって, T2症例では,
広範な硬膜切除に加え, 嗅球の切除を想定した準備を行 い，徹底した術中病理診断を行い，切除範囲を決定する 方針が妥当ではないかと考える。さらに，広範な硬膜切 除に加え, 嗅球切除を想定した準備に加え, 術後髄液漏 防止の観点から，頭蓋底再建に多層筋膜および有茎鼻中 隔粘膜弁を用いた再建を想定することも必要となる。

\section{結論}

今回, 内視鏡下経鼻手術を行った嗅神経芽細胞腫 5 例の 病理組織学的検查結果から, Dulguerov and Calcaterra の臨床病期分類に抢けるT1，あるいは，Kadish分類に 扔ける A， Bに対しては，穊板切除を行う片側切除を基 準術式が適することが示唆され, Dulguerov and Calcaterraの臨床病期分類におけるT2では，硬膜および 嗅系を含めた嗅神経経路の詳細な術中病理診断を行い, 切除範囲を決定すべきことが示唆された。全ての症例で, 術後合併症は認められず，術後放射線治療も速やかに行 うことが可能であり，片側切除を施行した 4 例中 3 例で 嗅覚機能が温存されたことから，今回用いた術式は，内 視鏡下経鼻手術の低侵襲性という利点を活かすものとい える。今回の結果を基盤として，本邦に扔ける嗅神経芽 細胞腫に対する内視鏡下経鼻手術の有效性解析を目的と した前向き臨床試験デザインを行いたいと考える。

\section{参考文献}

1) Lund VJ, Stammberger H, Nicolai P, et al : European Rhinologic Society Advisory Board on Endoscopic Techniques in the Management of Nose, Paranasal Sinus and Skull Base Tumours. European position paper on endoscopic management of tumours of the nose, paranasal sinuses and skull base. Rhinol Suppl. 2010 ; 22 : 1-143.

2 ) Devaiah AK, Andreoli MT : Treatment of esthesioneuroblastoma: a 16-year meta-analysis of 361 patients. Laryngoscope $2009 ; 119$ : 1412-1416.

3 ) Folbe A, Herzallah I, Duvvuri U, et al : Endoscopic endonasal resection of esthesioneuroblastoma: a multicenter study. Am J Rhinol Allergy 2009 ; 2 : 91-94.

4) Soler ZM, Smith TL : Endoscopic versus open craniofacial resection of esthesioneuroblastoma: what is the evidence? Laryngoscope $2012 ; 122$ : 244-245.

5 ) Kadish S, Goodman M, Wang CC : Olfactory neuroblastoma: a clinical analysis of 17 cases. Cancer 
$1976 ; 37: 1571-1576$.

6 ) Dulguerov P, Calcaterra T : Esthesioneuroblastoma: the UCLA experience 1970-1990. Laryngoscope $1992 ; 102: 843-849$.

$7)$ Hyams VJ : Olfactory neuroblastoma. In: Hyams VJ, Baksakis JG, Michaels L (eds). Tumors of the upper respiratory tract and ear. Armed Forces Institute of Pathology, Washington DC ; 1988 : p. $240-248$.

$8)$ Dulguerov P, Allal AS, Calcaterra TC : Esthesioneuroblastoma: a meta-analysis and review. Lancet Oncol $2001 ; 2: 683-690$.

9 ) Castelnuovo P, Bignami M, Delù G, et al : Endonasal endoscopic resection and radiotherapy in olfactory neuroblastoma: our experience. Head Neck 2007 ;
$29: 845-850$.

10) Unger $F$, Haselsberger $K$, Walch $C$, et al : Combined endoscopic surgery and radiosurgery as treatment modality for olfactory neuroblastoma (esthesioneuroblastoma). Acta Neurochir (Wien) 2005 ; 147 : 595-602.

11) Gallia GL, Reh DD, Salmasi V, et al : Endonasal endoscopic resection of esthesioneuroblastoma: the Johns Hopkins Hospital experience and review of the literature. Neurosurg Rev 2011 ; 34 : 465-475.

12) Kassam AB, Prevedello DM, Carrau RL, et al : Endoscopic endonasal skull base surgery: analysis of complications in the authors' initial 800 patients. J Neurosurg $2011 ; 114$ : 1544-1568. 